\title{
Ovitrap Index and Transovarial Transmission Rate of Dengue Virus of Male and Female Aedes aegypti Mosquitoes in Makassar, South Sulawesi, Indonesia
}

\author{
Isnadiyah Juhdi ${ }^{1 *}$, Loeki Enggar Fitri ${ }^{2}$, Lilik Zuhriyah ${ }^{3}$, Andi Arahmadany Arasy ${ }^{4}$ \\ ${ }^{1}$ Biomedical Science, Faculty of Medicine, Universitas Brawijaya, Malang 65145, Indonesia \\ ${ }^{2}$ Department of Parasitology, Faculty of Medicine, Universitas Brawijaya, Malang 65145, Indonesia \\ ${ }^{3}$ Department of Public Health, Faculty of Medicine, Universitas Brawijaya, Malang 65145, Indonesia \\ ${ }^{4}$ Center for Environmental Health Engineering and Disease Control Makassar, Makassar 90222, Indonesia
}

Article history:

Submission September 2018

Revised October 2018

Accepted January 2019

*Corresponding author:

E-mail:

isnadiyah.juhdi@yahoo.com.sg

\begin{abstract}
The incidence rate (IR) of dengue hemorrhagic fever (DHF) in Indonesia has increased in recent years and still causes a health problem. Makassar, as one of the big cities in Indonesia, is also experiencing of DHF cases. According to the Health Office of Makassar City, DHF cases during 2014 - 2016 has increased from 139 to 250 cases. The defense mechanism of dengue virus in transovarial transmission from female mosquitoes to eggs is estimated to be one of the factors that increase the rate of DHF. In addition, the circulation of the Aedes aegypti mosquitoes can also affect the increase of the rate. This study aims are to identify ovitrap index and to find out how much the vertical transmission of dengue virus by measuring the minimum infection rate (MIR) and the distribution of four dengue virus serotype in Ae. aegypti mosquitoes in the city of Makassar, South Sulawesi, as well as their association with the incidence rate (IR) in the area. This observational research uses ecological study with cross-sectional approach. The samples of the study are male and female mosquitoes from Ae.aegypti eggs obtained from the installation of ovitrap in 30 urban villages in Makassar. Dengue virus identification was performed using a reverse transcriptase polymerase chain reaction (RTPCR). These results showed that the ovitrap index (IO) was in the range of 0 $66.7 \%$. The average value of the ovitrap index outside the house $(44.44 \%)$ was greater than inside house (37.22\%). The results of identification of dengue virus using RT-PCR showed negative results as indicated by the non-formation of a band on 75 pools male and 78 pools female Ae. aegypti mosquitoes after electrophoresis. The results of this study indicated that the Ae. aegypti mosquito in Makassar City showed a tendency to lay eggs outside the house due to the habit of the people who put rain water shelters outside the house which could become breeding place for Ae. aegypti mosquitoes. This study also showed that there was no transovarial transmission of DENV found in male and female Ae. aegypti mosquitoes in Makassar City during November 2017 until January 2018.
\end{abstract}

Keywords: Transovarial transmission, dengue virus, Aedes aegypti, RT-PCR

\section{Introduction}

Dengue infection is a disease caused by the dengue virus, propagated by its biological vector, i.e. female Aedes aegypti as the main vector and Aedes albopictus as the secondary vectors, depending on the graphical location. It is estimated that about 3.9 billion people living in 128 countries are at the risk of being infected by the dengue virus [3]. Another study showed that there were 390 million cases of dengue infections each year with a total of 96 million cases showing clinical symptoms [4]. The clinical symptoms of dengue infection vary in the undifferentiated fever (viral syndrome), dengue fever (DF), dengue hemorrhagic fever (DHF) including dengue shock syndrome (DSS) and expanded dengue syndrome

\section{How to cite:}

Juhdi I, Fitri LE, Zuhriyah L, Arasy AA (2019) Ovitrap Index and Transovarial Transmission Rate of Dengue Virus of Male and Female Aedes aegypti Mosquitoes in Makassar, South Sulawesi, Indonesia. Journal of Tropical Life Science 9 (1): 95 103. doi: 10.11594/jtls.09.01.13 
[26]. Dengue virus infection is distributed in tropical and subtropical regions. The first case of dengue infection was discovered in 1950s during the epidemic dengue in the Philippines and Thailand. Currently, the case of dengue infection occurs in most Asian and American countries, and the Western Pacific, and it is the major cause of hospitalization and death in children and adults [18, 27]. In Southeast Asia, Indonesia places the first ranks in number of cases per year,152,052 in 2009 [26]. Makassar, the capital city of South Sulawesi province, is the gateway and trading center in eastern Indonesia. The city covers the area of $175.77 \mathrm{~km} 2$, divided into 15 districts with 153 villages. With the population of 1,769,920 in 2017, according to the Central Bureau of Statistics, the city became one of the cities in South Sulawesi with an increasing incidence rate (IR) of DHF during 2014-2016 [7]. Dengue virus survives in nature through two transmission mechanisms: horizontal and vertical. Horizontally, mosquitoes are infected from biting a viremic human and then transmit the virus to other humans by further biting. Vertically, or through transovarial transmission, female mosquitoes infected by dengue virus lay eggs that produce infectious larvae. This mechanism is very important for the survival of Dengue virus in nature because the eggs can survive in extreme environmental conditions for a long time; they even can survive for more than one year $[15,19]$. The study of transovarial transmission in Indonesia was first conducted by Umniyati in 2004 in Klitren of Yogyakarta, reporting a transovarial infection rate of $27.7 \%$ (TIR) through the application of immunohistochemistry streptavidin biotin peroxidase complex (ISBPC) on mosquito specimens. A similar study was conducted in 5 villages in Malalayang district of Manado, obtaining TIR value in the range of $6.1-13.3 \%$ [21].

The circulation of four types of serotypes of dengue virus throughout the year is also the cause of the increasing cases of dengue [21]. The serotypes (DENV-1, DENV-2, DENV-3 and DENV4), particularly DENV-2, are endemic in Indonesia. In 2015 Sasmono et al. reported that the distribution of Dengue virus serotype from patients in Makassar City was dominated by serotype DENV1 (41\%), followed by DENV-2 (31\%), DENV-3 (20\%), and DENV- 4 (7\%). However, the distribution of dengue virus serotypes from its vector in Makassar City has not been reported.
Previous studies show that there is many variable prevalence of the virus in adult mosquitoes including in their eggs and larvae. Also, there are still controversial opinions regarding which one of the four dengue serotypes is the best at transovarial transmission. Martins et al., in 2012, found 35 Ae. albopictus mosquitoes to be DENV3 positive, 50 Ae. aegypti mosquitoes to be infected with DENV-2, while 41 A. albopictus mosquitoes carry DENV-2 and DENV-3simultaneously. There was a minimum infection rate of 0.5 for Ae. aegypti and 9.4 for Ae. albopictus [14]. Another study found the vertical transmission of DEN 3 in male specimens of Ae. aegypti, collected in the 2009's fall-winter period, in Puerto Iguazú city, Misiones, Argentina [10].

In this research we have done collecting $A e$. aegypti eggs and detecting dengue virus serotype in reared adult male and female mosquitoes from Ae. aegypti eggs to see the value of transovarial transmission determined with minimum infection rate (MIR) in Makassar, South Sulawesi.

\section{Material and Methods \\ Research design and site selection}

This observational research uses ecological study through cross-sectional approach. This research was conducted in 30 of 153 urban villages in Makassar City. From each village, three houses were selected for ovitrap placement. The selection of the village was purposively done based on the data regarding the highest DHF patients during January-October 2017, and the selection of houses in each village was done randomly.

\section{Sampling, rearing and maintenance of samples of Ae. aegypti}

The sampling was conducted from November 2017 to January 2018, using an ovitrap from a black plastic bucket with $\pm 12 \mathrm{~cm}$ high and \pm 11 $\mathrm{cm}$ in diameter for egg collection. The inside part of the ovitrap was affixed with filter paper (ovistrip) [5]. The ovitrap was filled with hay infusion made by soaking 125 gram of hay in 15 liters of water in tightly closed plastic garbage for 7 days [16]. Two pieces of ovitraps were placed in each house, indoor and outdoor. Water attractiveness was checked and replaced every 3 days, and the ovitraps were placed in every house for $9-12$ days. 
After 9-12 days, the eggs in the ovistrip were collected and hatched on a tray that has been filled with water for $2-3$ days. The newly hatched larvae were not fed for 24 hours. After 24 hours the larvae were removed and then fed with larvae feed. After 5 - 7 days, the larvae that have transformed into pupa were replaced from the breeding place using pipette and placed in small plastic cups, then placed in mosquito coop and left for 12 days to became adult mosquitoes. The adult mosquitoes were separated in a cage measuring 20 $\times 20 \times 20 \mathrm{~cm}$ and kept until 7 days old by feeding only $10 \%$ sugar water.

\section{Extraction of RNA}

The extraction was performed by taking all parts of the mosquito's body, except wings and feet, and crushing it in $500 \mu \mathrm{L}$ of phosphate buffer saline (PBS) $\mathrm{pH} 7.0$, and adding it $500 \mu \mathrm{L}$ of PBS once more before transferring it to microtube sterile. The sample was added with $25 \mu \mathrm{l}$ of proteinase $\mathrm{K}$, mixed by vortex and centrifuged at $2000 \mathrm{rpm}$ at $4^{\circ} \mathrm{C}$ for 5 minutes. As much as $250 \mu \mathrm{L}$ of supernatant is added with $750 \mu \mathrm{L}$ of trizole solution, mixed with vortex and incubated at $4^{\circ} \mathrm{C}$ for 2 minutes. Later, $200 \mu \mathrm{L}$ cold chloroform was added, mixed by vortex and incubated for 2 minutes at $4^{\circ} \mathrm{C}$. After the incubation, the samples were centrifuged at $4^{\circ} \mathrm{C}$ for 5 minutes at 10,000 rpm. Two layers were formed after centrifugation; the top layer was clear colored, and the bottom layer was pink. The upper layer (supernatant) was transferred into a $1.5 \mathrm{~mL}$ sterile tube. The supernatant was added with $0.1 \mu$ l glycogen to bind the RNA and $750 \mu$ of cold ethanol absolute, mixed by vortex and incubated at $4^{\circ} \mathrm{C}$ for 15 minutes. The sample was then centrifuged at $4^{\circ} \mathrm{C}$ for 10 minutes at 10,000 rpm. RNA was formed as a pellet at the end of the tube. The next processes were washing it using $500 \mu \mathrm{L}$ of $70 \%$ cold ethanol and incubating it for 2 minutes at $4^{\circ} \mathrm{C}$, followed by centrifugation for 5 minutes at $4^{\circ} \mathrm{C}$ at $10,000 \mathrm{rpm}$. RNA pellet was melted by adding $25 \mu \mathrm{L}$ of RNAse free water. The extraction results were then tested for purity and concentration using QIA-xpert from Qiagen.

\section{Detection of dengue virus with RT-PCR}

For viral identification with RT-PCR, the sample was run with Rotor Gene PCR from Qiagen used SuperScriptTM III Reverse Transcriptase kit
Invitrogen based on manual kit, with four stages, first stage is a synthesis of c-DNA, done at $50^{\circ} \mathrm{C}$ for 45 minutes, second is a hot start at $95^{\circ} \mathrm{C}$ for 15 minutes, third stage is a cycling stage, consisting of 40 cycles with the following stages are denaturation at $92^{\circ} \mathrm{C}$ for 30 seconds, annealing at $58^{\circ} \mathrm{C}$ for 1 minute, extension at $72^{\circ} \mathrm{C}$ for 2 minutes. The last stage is a final extension at the temperature of $72^{\circ} \mathrm{C}$ for 2 minutes

Primer used in the identification of virus by RT-PCR was a consensus of primary dengue virus (D1 and D2) and primary TS (type-specific) of the four serotypes [13]. Four primary TS were used when getting positive result in the first RT-PCR process [24].

\section{Results and Discussion \\ Incidence Rate (IR) of DHF in 30 villages in Makassar City}

The highest number of DHF cases is 7 cases that occurred in Pisang Utara village, while the lowest was in Mamajang Dalam (0 cases). The highest incidence of DHF was in Pisang Utara village $(15,8 \%)$ and the lowest was in Mamajang Dalam (0\%). The data of DHF incidence per 10,000 inhabitants in 30 villages in 2017 are presented in Table 1.

\section{Ovitrap Index (OI) in 30 villages in Makassar City}

Table 2 represented distribution of ovitrap and ovitrap index in 30 villages in Makassar. The result of mosquitoe's egg collection showed the outdoor ovitrap index (OI) was $44.44 \%$, higher than indoor OI (37.22\%).

The highest indoor OI was $66.67 \%$ founded in Maricaya Selatan village, Mamajang Luar village and PAI village, while the lowest indoor OI was in Panambungan village $(0 \%)$. The highest outdoor OI was $66.67 \%$, founded in Maricaya Selatan village, Panambungan village, Rappojawa village and Lembo village, whereas the lowest was founded in 3 villages (16.67\%).

\section{RNA extraction of male and female Ae. aegypti}

The mean of RNA extract concentration on reared adult of Ae. aegypti mosquitoes are showed in Table 3. The mean of RNA extract concentration was achieved from male and female mosquitoes was $180.2 \mathrm{ng} / \mu \mathrm{L}$ and $314.03 \mathrm{ng} / \mu \mathrm{L}$, respectively. The differences between RNA concentra- 
Table 1. Incidence rate (IR) of DHF in 30 urban villages in Makassar

\begin{tabular}{|c|c|c|c|c|}
\hline No. & Villages & The number of cases ${ }^{a}$ & $\begin{array}{c}\text { The number of } \\
\text { population }^{\mathrm{b}}\end{array}$ & $\begin{array}{c}\text { IR } \\
\text { (per } 10.000 \text { population) }^{c}\end{array}$ \\
\hline 1. & Bontomakio & 1 & 5,150 & 1.9 \\
\hline 2. & Karunrung & 1 & 14,110 & 0.7 \\
\hline 3. & Mapala & 1 & 9,745 & 1.0 \\
\hline 4. & Bantabantaeng & 2 & 23,117 & 0.9 \\
\hline 5. & Maricaya Selatan & 6 & 5,471 & 11 \\
\hline 6. & Mamajang Luar & 2 & 3,653 & 5.5 \\
\hline 7. & Mamajang Da- & 0 & 3,327 & 0 \\
\hline 8. & lam & 1 & 3,596 & 2.8 \\
\hline 9. & Mandala & 2 & 8,341 & 2.4 \\
\hline 10. & Maccini Gusung & 1 & 7,268 & 1.4 \\
\hline 11. & Maccini Sawah & 1 & 4,684 & 2.1 \\
\hline 12. & Mario & 2 & 12,235 & 1.6 \\
\hline 13. & Panambungan & 1 & 9,428 & 1.1 \\
\hline 14. & Lette & 1 & 8,159 & 1.2 \\
\hline 15. & Mariso & 3 & 6,376 & 4.7 \\
\hline 16. & Rappojawa & 3 & 7,560 & 4.0 \\
\hline 17. & Wala-walaya & 2 & 22,678 & 4.0 \\
\hline 18. & KalukuBodoa & 2 & 9,166 & 0.9 \\
\hline 19. & B.E Beru & 2 & 11,625 & 1.7 \\
\hline 20. & Lembo & 4 & 23,263 & 1.7 \\
\hline 21. & Pai & 4 & 51,736 & 0.9 \\
\hline 22. & Sudiang Raya & 1 & 2,438 & 4.1 \\
\hline 23. & Laikang & 2 & 13,027 & 1.5 \\
\hline 24. & Maccini Sombala & 1 & 11,200 & 0.9 \\
\hline 25. & Tanjung Merdeka & 3 & 10,787 & 2.8 \\
\hline 26. & Karampuang & 2 & 18,071 & 1.1 \\
\hline 27. & Pampang & 1 & 16,190 & 0.6 \\
\hline 28. & Panaikang & 7 & 4,420 & 15.8 \\
\hline 29. & Pisang Utara & 1 & 6,114 & 1.6 \\
\hline 30. & $\begin{array}{l}\text { Lajangniru } \\
\text { Pabaeng-baeng }\end{array}$ & 4 & 20,342 & 2.0 \\
\hline
\end{tabular}

Note:

$\mathrm{a}=$ Data source from Makassar Health City Office

$\mathrm{b}=$ Data source from Makassar City Statistic Centre

$c=(a / b) \times 10.000$

tion in male and female mosquitoes due to differences in body size of male and female mosquitoes. The body size of female larger than male, so the concentration of RNA extract in females more than males. The result of RNA purity measurement of male and female was $1.51-2.24$ and 1.56 -2.08 . This result showed that some of samples have value of purity less than 1.9 (the value of RNA extract purity is $1.9-2.1$ ). However, these values were allowed to continue the process of virus RNA identification using RT-PCR.

\section{Detection of dengue virus in male and female Ae- des aegypti mosquitoes}

Figure 2 exhibited the result of RT-PCR identification using primer pair D1 and D2 [13]. The data represented nine sample pools of male and female mosquitoes collected from three villages. In Figure 2.a and 2.b, a 100 bp DNA ladder marker placed on the first column, a positive control on the second column, a negative control on the third column and nine samples in the fourth to the twelfth column. Electrophoresis results showed all 
Table 2. The distribution of ovitrap and ovitrap index in 30 villages in Makassar

\begin{tabular}{|c|c|c|c|c|c|c|c|c|c|c|}
\hline \multirow{3}{*}{ No. } & \multirow{3}{*}{ Village } & \multirow{2}{*}{\multicolumn{2}{|c|}{ Amount of Ovitrap }} & \multicolumn{4}{|c|}{ Eggs existence } & \multirow{2}{*}{\multicolumn{2}{|c|}{ Ovitrap Index (\%) }} & \multirow{3}{*}{$\begin{array}{c}\% \\
\text { Total }\end{array}$} \\
\hline & & & & \multicolumn{2}{|c|}{ Positive } & \multicolumn{2}{|c|}{ Negative } & & & \\
\hline & & indoor & outdoor & indoor & outdoor & indoor & outdoor & indoor & outdoor & \\
\hline 1. & Bontomakio & 6 & 6 & 3 & 3 & 3 & 3 & 50 & 50 & 50 \\
\hline 2. & Karunrung & 6 & 6 & 1 & 3 & 5 & 3 & 16.67 & 50 & 33.33 \\
\hline 3. & Mapala & 6 & 6 & 1 & 3 & 5 & 3 & 16.67 & 50 & 33.33 \\
\hline 4. & Bantabantaeng & 6 & 6 & 3 & 3 & 3 & 3 & 50 & 50 & 50 \\
\hline 5. & Mar.Selatan & 6 & 6 & 4 & 4 & 2 & 2 & 66.67 & 66.67 & 66.67 \\
\hline 6. & Mam. Luar & 6 & 6 & 4 & 1 & 1 & 5 & 66.67 & 16.67 & 41.46 \\
\hline 7. & Mam.Dalam & 6 & 6 & 3 & 3 & 3 & 3 & 50 & 50 & 50 \\
\hline 8. & Mandala & 6 & 6 & 3 & 3 & 3 & 3 & 50 & 50 & 50 \\
\hline 9. & Mac.Gusung & 6 & 6 & 3 & 3 & 3 & 3 & 50 & 50 & 50 \\
\hline 10. & Mac. Sawah & 6 & 6 & 3 & 3 & 3 & 3 & 50 & 50 & 50 \\
\hline 11. & Mario & 6 & 6 & 3 & 3 & 3 & 3 & 50 & 50 & 50 \\
\hline 12. & Panambungan & 6 & 6 & 0 & 4 & 6 & 2 & 0 & 66.67 & 33.33 \\
\hline 13. & Lette & 6 & 6 & 3 & 1 & 3 & 5 & 50 & 16.67 & 33.33 \\
\hline 14. & Mariso & 6 & 6 & 1 & 3 & 5 & 3 & 16.67 & 50 & 33.33 \\
\hline 15. & Rappojawa & 6 & 6 & 2 & 4 & 4 & 2 & 33.33 & 66.67 & 50 \\
\hline 16. & Walaya & 6 & 6 & 1 & 2 & 5 & 4 & 16.67 & 33.33 & 25 \\
\hline 17. & Kalukubodoa & 6 & 6 & 1 & 3 & 5 & 2 & 16.67 & 50 & 33.33 \\
\hline 18. & BE. Beru & 6 & 6 & 1 & 1 & 5 & 5 & 16.67 & 16.67 & 16.67 \\
\hline 19. & Lembo & 6 & 6 & 3 & 4 & 3 & 2 & 50 & 66.67 & 58.53 \\
\hline 20. & Pai & 7 & 4 & 4 & 2 & 2 & 2 & 66.7 & 50 & 54.54 \\
\hline 21. & Sudiang raya & 6 & 6 & 2 & 3 & 4 & 3 & 33.33 & 50 & 41.67 \\
\hline 22. & Laikang & 6 & 6 & 2 & 3 & 4 & 3 & 33.33 & 50 & 41.67 \\
\hline 23. & Mac.Sombala & 6 & 6 & 2 & 3 & 4 & 3 & 33.33 & 50 & 41.67 \\
\hline 24. & Tanjung M & 6 & 6 & 2 & 2 & 3 & 4 & 33.33 & 33.33 & 33.33 \\
\hline 25. & Karampuang & 6 & 6 & 2 & 3 & 4 & 2 & 33.33 & 33.33 & 33.33 \\
\hline 26. & Pampang & 6 & 6 & 2 & 3 & 3 & 2 & 33.33 & 33.33 & 33.33 \\
\hline 27. & Panaikang & 6 & 6 & 2 & 3 & 4 & 2 & 33.33 & 33.33 & 33.33 \\
\hline 28. & Pisang Utara & 6 & 6 & 2 & 3 & 4 & 2 & 33.33 & 33.33 & 33.33 \\
\hline 29. & Lajangniru & 6 & 6 & 2 & 3 & 4 & 1 & 33.33 & 33.33 & 33.33 \\
\hline 30. & Pabaengbaeng & 6 & 6 & 2 & 2 & 4 & 4 & 33.33 & 33.33 & 33.33 \\
\hline & & & Average & & & & & 37.22 & 44.22 & 42.09 \\
\hline
\end{tabular}

of the samples did not form any band. These results indicated that the RNA samples did not carried dengue virus.

This research suggests the effectivity of hay infusion for ovitrap; from 90 locations of ovitrap placement, 78 of them, or about $86.67 \%$, became the place for female Ae. aegypti to lay eggs. The infusion contains ammonia and $\mathrm{CO}_{2}$ derived from the metabolism process, which is able to attract Aedes mosquitoes for breeding through its smell [8].

The ovitrap index (OI) of this study site ranges from $16.67 \%$ to $66,67 \%$ with the mean of $42.9 \%$. The outdoor index is higher (44.22\%) than the in- door (37,44\%). This suggests that Ae. aegypti mosquitoes in Makassar tend to lay eggs outside the house. This result is similar to the results of the research in 10 villages in Pontianak, where the outside OI (41\%) was higher than the inside OI (20.8\%) because Ae. aegypti prefer spawning outdoors to indoors [22].

The sample collection was conducted from November 2017 to January 2018, in rainy season. The age of mosquitoes is longer during this season, so the transmission of the virus is higher [20]. Although large rainfall can wash away the mosquitoes, the stagnant remains of rainwater become a potential breeding places for larvae and adult 
Table 3. Concentration and purity of RNA extract of male and female mosquitoes

\begin{tabular}{cccccc}
\hline \multirow{2}{*}{ No. } & \multirow{2}{*}{ Extraction } & \multicolumn{2}{c}{ Range } & \multicolumn{2}{c}{ Mean } \\
\cline { 3 - 6 } & & Concentration & Purity & Concentration & Purity \\
\hline 1. & Male & $10.4-628$ & $1.51-2.24$ & 180.2 & 1.79 \\
2. & Female & $20.8-1167$ & $1.56-2.08$ & 314.03 & 1.87 \\
\hline
\end{tabular}

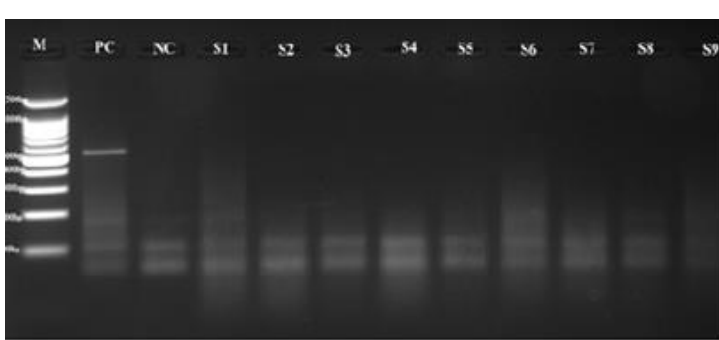

(a)

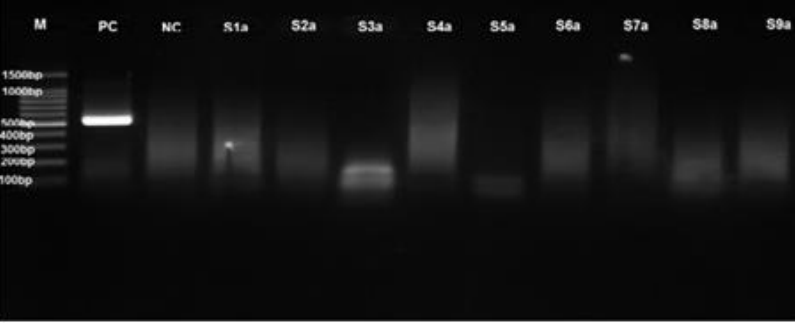

(b)

Figure 2. The result of identification of dengue virus with RT-PCR method in female (a) and male Ae.aegypti mosquitoes used the DENV-1 as a control

mosquitoes [1, 11].

Throughout 2007 - 2017 DHF cases in Makassar city fluctuated. The interaction of various factors, physical and biological as well as social environment, influences the transmission of dengue virus. One of the environmental factors that plays an important role in this transmission is climatic factor. Climate plays an important role in triggering the development of vector populations, viral propagation, and virus transmission to humans [1, 24].

Increasing environmental temperature can shorten gonotrophic cycles and reduce extrinsic periods. At higher temperatures, infected adult mosquitoes require more blood intake to complete the gonotrophic cycle that occurs throughout their life cycle, allowing increased risk of dengue transmission [1, 6]. Although the average temperature in the city of Makassar does not increase significantly every month, the average temperature ranges from $27^{\circ} \mathrm{C}$ to $32^{\circ} \mathrm{C}$, so dengue virus transmission can still occur throughout the year.

In rainy season, when the temperature becomes low, Ae. aegypti mosquitoes can survive in the temperature of up to $10^{\circ} \mathrm{C}$, but their metabolism decreases or even stops when the air temperature is below $4.5^{\circ} \mathrm{C}$, which ultimately affects the development of the virus in the mosquito body, biting rate, rest time and mating behavior, dispersal and duration of gonotrophic cycles [2]. Humidity is also a factor that can affect the rate of dengue virus transmission. Relative humidity affects survival, mating, spreading, feeding behavior, and placement of mosquito eggs in its habitat (oviposition) as well as virus replication period in mosquito [17].

In this study, no positive results of dengue virus in both reared adult male and female of Ae. aegypti mosquitoes with the MIR value of 0 , showing that the transovarial transmission does not occur in 30 urban villages in Makassar in rainy season. This is similar to the transovarial transmission research in Cebu City of Philippines in 86 pools of Ae. aegypti mosquito samples in rainy season and in 85 pools in dry season. Infected MIR mosquitoes increased from 0 in rainy season to 48.22 per 1000 mosquitoes in the middle of dry season [9]. Similar results were also obtained from a study conducted in southern India in 204 samples of pools of female Ae. aegypti obtained in rainy season with the MIR value of 0 [23].

Different results were obtained from a study conducted by Mulyatno et al. (2012) in Surabaya during 2008-2011'srainy and dry season, in which the MIR values in reared adult female mosquito in rainy season of 2009 is 11.4, in the rainy season of 2011 is 22.1, and in the dry season of 2010 is 8.0. This study shows that the acquisition of MIR values in adult male mosquitoes is 5.7 and 8.8 in the rainy season of 2009 and 2011. The differences may occur due to differences in research sites and sample collection duration. Surabaya is a dengue 
endemic area with a number of cases reaching 2,000 to 3,000 per year [15], whereas the location of this study is a sporadic area with an incidence rate of below 20 per 100,000 population.

Another factor that can cause the negative result of dengue virus on Ae. aegypti is the fogging program conducted by the Health Department of Makassar City, which was done every time DHF case occur in a region. Based on the data from Makassar City's Health Office in 2017, in thirty villages used as the research sites, fogging was done at least one week after the occurrence of DHF case. Therefore, it is possible that Ae. aegypti mosquitoes that have been infected by dengue virus have died due to fogging. Fogging is done to exterminate dengue mosquitos carrying disease, one of them is Ae. aegypti mosquito. It is done in the area around the patient's house until the radius of 100 - 200 meters. Some studies have demonstrated the effectiveness of fogging in increasing the percentage of free larvae and reducing the percentage of larvae [12, 30]

However, fogging with malathion only kills adult mosquitoes, and it does not kill the existing larva, so the larva in the target area can still develop into adult mosquito. However, not all larvae that develop into adult mosquitoes carry dengue virus. Another possibility is that the eggs obtained as the sample of this study is the second generation of mosquitoes that carry dengue virus, so the concentration of dengue virus might be reduced or disappear.

The methods that were used in this study can also be the factor of the failure of finding positive results. The transovarial transmission study conducted by Wanti et al. (2016) using two methods of dengue virus detection in female Ae. aegypti, i.e. IHC and RT-PCR from the same area, found the different result. Some sample that tested with IHC method get the positive result, but it is negative when it is done using RT-PCR method [25].

Another transovarial transmission study in 3 villages in Banyumas also showed different result when using different method i.e. RT-PCR and IHC method with the same sample. Dengue virus negative result were obtained from Ae. aegypti sample that had been detected positive for dengue virus using the IHC method [29]. Both results of the study show the sensitivity of the IHC method compared to RT-PCR method in detecting dengue virus, but RT-PCR is more specific in detecting den- gue virus [28]

The negative result indicated in this study suggests the success of the Health Office of Makassar City in their program of vector control containing dengue virus. However, it does not mean that the government can reduce the vigilance against the spread of dengue virus, considering that there are still many dengue virus-carrying vectors and that Ae. aegypti is not only the vector of dengue virus but also the vector of zika virus, whose symptoms are similar to those of dengue virus infection.

\section{Conclusion}

This study shows the absence of the transovarial transmission of Makassar city throughout November 2017 until January 2018 with no positive results of dengue virus in Ae. aegypti mosquitoes found in reared adult males and females Ae. aegypti mosquitoes.

Although no positive results were found in the Ae. aegypti mosquito males and females from eggs as a carrier vector for dengue virus, vigilance against dengue virus infection must still be done through surveillance and vector control.

For further research it should be carried out in areas that have an incidence rate of above 20 per 100,000 population or carried out in the dry season where the ambient temperature is higher.

\section{Acknowledgment}

Our thanks to the Head of Master Program in Biomedical Science, Faculty of Medicine Universitas Brawijaya, Head of Makassar Environmental Engineering Center and staffs in the Laboratory Engineering Development section for its support during this research. We also thank to the sanitarians of 14 health center community (Puskesmas) in Makassar who have assisted in the sample collection process.

\section{References}

1. Atique S, Abdul SS, Hsu CY, Chuang TW (2016) Meteorological influences on dengue transmission in Pakistan. Asian Pacific Journal of Tropical Medicine 9 (10): 954-961. doi: 10.1016/j.apjtm.2016.07.033.

2. Bangkele EY, Safriyanti N (2016) Hubungan suhu dan kelembapan dengan kejadian demam berdarah dengue (DBD) di Kota Palu Tahun 2010 - 2014. Medika Tadulako: Jurnal Ilmiah Kedokteran Fakultas Kedokteran dan Ilmu Kesehatan 3 (2): 40 -50 . 
3. Bhatt S, Gething PW, Brady OJ et al. (2013) The global distribution and burden of dengue. Nature 496 (7446): 504-507. doi: 10.1038/nature12060.

4. Brady OJ, Gething PW, Bhatt S et al. (2012) Refining the global spatial limits of dengue virus transmission by evidence-based consensus. PLoS Neglected Tropical Diseases 6 (8): e1760. doi: 10.1371/journal.pntd.0001760.

5. Budiyanto A (2010) Pengaruh perbedaan warna ovitrap terhadap jumlah telur nyamuk Aedes spp. yang terperangkap. Aspirator 2 (2): 99 - 102.

6. Cheong Y, Burkart K, Leitão P, Lakes T (2013) Assessing weather effects on dengue disease in Malaysia. International Journal of Environmental Research and Public Health 10 (12): 6319 - 6334. doi: 10.3390/ijerph10126319.

7. Dinas Kesehatan Kota Makassar (2017) Profil kesehatan Kota Makassar tahun 2016. Makassar, Pemerintah Kota Makassar.

8. Dwinata I, Satoto TUB, Indriani C (2015) Autocidal ovitrap aktraktan rendaman jerami. The Indonesian Journal of Public Health 11 (2): 125 - 131.

9. Edillo FE, Sarcos JR, Sayson SL (2015) Natural vertical transmission of dengue viruses in Aedes aegypti in selected sites in Cebu City, Philippines. Journal of Vector Ecology 40 (2): 282 291. doi: 10.1111/jvec.12166.

10. Espinosa M, Giamperetti S, Abril M, Seijo A (2014) Vertical transmission of dengue virus in Aedes aegypti collected in Puerto Iguazu, Misiones, Argentina. Revista do Instituto de Medicina Tropical de São Paulo 56 (2): 165 - 167. doi: 10.1590/S0036-46652014000200013.

11. Gu H, Leung R, Jing Q et al. (2016) Meteorological factors for dengue fever control and prevention in South China. International Journal of Environmental Research and Public Health 13 (9): 867. doi: 10.3390/ijerph13090867.

12. Ibrahim E, Hadju V, Nurdin A, Ishak H (2016) Effectiveness of abatezation and fogging intervention to the larva density of $\mathrm{Ae}$ des aegypti dengue in endemic areas of Makassar City. International Journal of Sciences 30 (3): 255 - 264.

13. Lanciotti RS, Calisher CH, Gubler DJ et al. (1992) Rapid detection and typing of dengue viruses from clinical samples by using reverse transcriptase-polymerase chain reaction. Journal of Clinical Microbiology 30 (3): 545 - 551.

14. Martins VEP, Alencar CH, Kamimura MT et al. (2012) Occurrence of natural vertical transmission of Dengue-2 and Dengue3 Viruses in Aedes aegypti and Aedes albopictus in Fortaleza, Ceará, Brazil. PLoS ONE 7 (7): 1 - 7. doi: 10.1371/journal.pone.0041386.

15. Mulyatno KC, Yamanaka A, Yotopranoto S, Konishi E (2012) Vertical transmission of dengue virus in Aedes aegypti collected in Surabaya, Indonesia, during 2008 - 2011. Japanese Journal of Infectious Diseases 65 (3): 274 - 276. doi 10.7883/yoken.65.274
16. Polson KA, Curtis C, Seng CM et al. (2002) The Use of ovitraps baited with hay infusion as a surveillance tool for Aedes aegypti Mosquitoes in Cambodia. Dengue Bulletin 26: 178 - 184.

17. Promprou S, Jaroensutasinee M, Jaroensutasinee K (2005) Climatic factors affecting dengue haemorrhagic fever incidence in Southern Thailand. Dengue Bulletin 29: 41 - 48.

18. Sasmono RT, Wahid I, Trimarsanto H et al. (2015) Genomic analysis and growth characteristic of dengue viruses from Makassar, Indonesia. Infection, Genetics and Evolution 32 165177. doi: 10.1016/j.meegid.2015.03.006.

19. Seran MD, Prasetyowati H (2014) Transmisi transovarial virus dengue pada telur nyamuk Aedes aegypti (L.). Aspirator 1 (2): 53-58.

20. Soedarto (2012) Demam berdarah. Jakarta, CV. Sagung Seto.

21. Sorisi AMH, Umniyati SR, Satoto TBU (2013) Transovarial transmission indeks of dengue virus on Aedes aegypti and Aedes albopictus mosquitoes in Malalayang district in Manado, North Sulawesi, Indonesia. Tropical Medical Journal 1 (2): 87 -95 .

22. Sucipto, Dani C, Umniyati SR (2009) Deteksi transmisi transovarial virus dengue pada nyamuk Aedes aegypti (Diptera: Culicidae) jantan dan betina serta hubungannya dengan incidence rate demam berdarah di Kota Pontianak. Doctoral Thesis. Universitas Gadjah Mada

23. Thenmozhi V, Hiriyan JG, Tewari SC et al. (2007) Natural vertical transmission of dengue virus in Aedes albopictus (Diptera: Culicidae) in Kerala, a Southern Indian State. Japanese Journal of Infectious Diseases 60: 245 - 249.

24. Tjahjasari AM (2009) Deteksi dan penentuan serotipe virus dengue tipe 4 dari nyamuk Aedes aegypti dengan menggunakan metode Reverse Transcriptase-Polymerase Chain Reaction (RT-PCR) di Kota Medan. Master Thesis. Universitas Sumatera Utara

25. Wanti, Sila O, Sinaga E (2016) Transovarial transmission and dengue virus serotypes in Aedes aegypti in Kupang. Jurnal Kesehatan Masyarakat 12 (1): 131-138.

26. WHO (2011) Comprehensive guidelines for prevention and control of dengue hemorrhagic fever revised and expand edition, India. New Delhi, Searo Technical Publication.

27. WHO (2017) Dengue and severe dengue. https://www.who.int/. Accessed: September 2018.

28. Widiastuti D, Yunianto B, Umniyati SR, Wijayanti N (2011) Sensitivity and specitivity of immunocytochemical assay for detection of dengue virus 3 in mosquito. Health Science Indonesia 2 (2): $87-91$

29. Wijayanti SP, Anandari D, Magfirah F (2017) Vertical transmission of dengue virus on field mosquitoes in Banyumas Regency, Central Java. Indonesia. International Journal of Public Health and Clinical Sciences 4 (3): 109 - 119. 
I Juhdi, LE Fitri, L Zuhriyah, AA Arasy, 2019 / Transovarial Transmission of Dengue Virus

30. Yee LY, Heryaman H, Faridah L (2017) The relationship between frequency of fogging focus and incidence of dengue hem- orrhagic fever cases in Bandung in year 2010 - 2015. International Journal of Community Medicine and Public Health 4 (2): 456. doi: 10.18203/2394-6040.ijcmph20170272. 
This page is intentionally left blank. 